\title{
Effects of the Photosystem II Inhibitors CCCP and DCMU on Hydrogen Production by the Unicellular Halotolerant Cyanobacterium Aphanothece halophytica
}

\author{
Sunisa Pansook, ${ }^{1}$ Aran Incharoensakdi, ${ }^{2,3}$ and Saranya Phunpruch (iD) \\ ${ }^{1}$ Department of Biology, Faculty of Science, King Mongkut's Institute of Technology Ladkrabang, Bangkok 10520, Thailand \\ ${ }^{2}$ Laboratory of Cyanobacterial Biotechnology, Department of Biochemistry, Faculty of Science, \\ Chulalongkorn University, Bangkok 10330, Thailand \\ ${ }^{3}$ Academy of Science, Royal Society of Thailand, Bangkok 10300, Thailand \\ ${ }^{4}$ Bioenergy Research Unit, Faculty of Science, King Mongkut's Institute of Technology Ladkrabang, Bangkok 10530, Thailand
}

Correspondence should be addressed to Saranya Phunpruch; saranya.ph@kmitl.ac.th

Received 8 February 2019; Revised 3 June 2019; Accepted 11 June 2019; Published 27 June 2019

Academic Editor: Mehmet Yakup Arica

Copyright (c) 2019 Sunisa Pansook et al. This is an open access article distributed under the Creative Commons Attribution License, which permits unrestricted use, distribution, and reproduction in any medium, provided the original work is properly cited.

The unicellular halotolerant cyanobacterium Aphanothece halophytica is a potential dark fermentative producer of molecular hydrogen $\left(\mathrm{H}_{2}\right)$ that produces very little $\mathrm{H}_{2}$ under illumination. One factor limiting the $\mathrm{H}_{2}$ photoproduction of this cyanobacterium is an inhibition of bidirectional hydrogenase activity by oxygen $\left(\mathrm{O}_{2}\right)$ obtained from splitting water molecules via photosystem II activity. The present study aimed to investigate the effects of the photosystem II inhibitors carbonyl cyanide m-chlorophenyl hydrazone (CCCP) and 3-(3,4-dichlorophenyl)-1,1-dimethylurea (DCMU) on $\mathrm{H}_{2}$ production of A. halophytica under light and dark conditions and on photosynthetic and respiratory activities. The results showed that A. halophytica treated with CCCP and DCMU produced $\mathrm{H}_{2}$ at three to five times the rate of untreated cells, when exposed to light. The highest $\mathrm{H}_{2}$ photoproduction rates, $2.26 \pm 0.24$ and $3.63 \pm 0.26 \mu \mathrm{mol} \mathrm{H} \mathrm{g}^{-1}$ dry weight $\mathrm{h}^{-1}$, were found in cells treated with $0.5 \mu \mathrm{M}$ CCCP and $50 \mu \mathrm{M}$ DCMU, respectively. Without inhibitor treatment, $A$. halophytica incubated in the dark showed a significant increase in $\mathrm{H}_{2}$ production compared with cells that were incubated in the light. Only CCCP treatment increased $\mathrm{H}_{2}$ production of $A$. halophytica during dark incubation, because CCCP functions as an uncoupling agent of oxidative phosphorylation. The highest dark fermentative $\mathrm{H}_{2}$ production rate of $39.50 \pm 2.13 \mu \mathrm{mol} \mathrm{H}_{2} \mathrm{~g}^{-1}$ dry weight $\mathrm{h}^{-1}$ was found in cells treated with $0.5 \mu \mathrm{M}$ CCCP after $2 \mathrm{~h}$ of dark incubation. Under illumination, CCCP and DCMU inhibited chlorophyll fluorescence, resulting in a low level of $\mathrm{O}_{2}$, which promoted bidirectional hydrogenase activity in A. halophytica cells. In addition, only CCCP enhanced the respiration rate, further reducing the $\mathrm{O}_{2}$ level. In contrast, DCMU reduced the respiration rate in A. halophytica.

\section{Introduction}

Molecular hydrogen $\left(\mathrm{H}_{2}\right)$ has attracted a great deal of interest from researchers because $\mathrm{H}_{2}$ combustion liberates a high heating value with $141.6 \mathrm{MJ} \mathrm{kg}^{-1}$ [1] and does not emit polluting gases to the environment. $\mathrm{H}_{2}$ production is a result of many processes, including physical, chemical, and biological processes. Biological $\mathrm{H}_{2}$ production can be established in many kinds of microorganisms such as photosynthetic bacteria, fermentative bacteria, green algae, and cyanobacteria [2]. Among these microorganisms, cyanobacteria show high capability because they can generate $\mathrm{H}_{2}$ using electrons obtained from a light reaction of the photosynthetic pathway and/or from the degradation of storage carbohydrates within cells in darkness $[3,4]$.

The unicellular cyanobacterium Aphanothece halophytica is a halotolerant microorganism that can grow in a wide range of salinity from 0.25 to $3.0 \mathrm{M} \mathrm{NaCl}$ [5]. A. halophytica produces a large amount of dark fermentative $\mathrm{H}_{2}$ compared with other marine cyanobacteria $[6,7] . \mathrm{H}_{2}$ production by $A$. halophytica is catalyzed by bidirectional hydrogenase and occurs particularly under nitrogen-deprived and dark 
anaerobic conditions [6-8]. Hydrogenase is the only enzyme that catalyzes both $\mathrm{H}_{2}$ uptake and $\mathrm{H}_{2}$ production in this organism [8]. Due to the high sensitivity of bidirectional hydrogenase to oxygen $\left(\mathrm{O}_{2}\right)$ [9], which is the main product when photosystem II (PSII) activity splits a water molecule, $\mathrm{H}_{2}$ production by $A$. halophytica decreases in the light [7]. To enhance $\mathrm{H}_{2}$ production by $A$. halophytica, $\mathrm{O}_{2}$ must be removed. One way to eliminate the generation of $\mathrm{O}_{2}$ from splitting water molecules during photolysis is to use photosystem II inhibitors.

Carbonyl cyanide m-chlorophenyl hydrazone (CCCP) has long been recognized as a photosystem II inhibitor of cyanobacteria and green algae [10]. CCCP has been shown to inhibit the photochemical activity of PSII under illumination in cyanobacteria Synechocystis sp. PCC 6803 [11], Synechococcus sp. PCC 7942 [12], Nostoc sp., and Lyngbya sp. [13] and green algae Chlorella ellipsoidea [14] and Platymonas subcordiformis [15]. This inhibition leads to a decrease in $\mathrm{O}_{2}$ production. CCCP can also function as an uncoupling agent of oxidative phosphorylation [16]. It disrupts the proton motive force by releasing protons across the thylakoid membrane, resulting in an inhibition of ATP synthesis. Consequently, a large number of electrons and protons can be transferred to bidirectional hydrogenase to enhance $\mathrm{H}_{2}$ production [17]. It has been reported that CCCP increased $\mathrm{H}_{2}$ production in the cyanobacteria Oscillatoria chalybea and Synechocystis sp. PCC 6803 [18] and in the green algae Chlamydomonas reinhardtii [19], P. subcordiformis [17, 20, 21], and Platymonas helgolandica var. tsingtaoensis [22]. In addition, this inhibition of ATP synthesis resulted in an increase in the rate of dark respiration in cyanobacteria Anabaena variabilis [23] and Anacystis nidulans [24] and green alga C. reinhardtii [25].

Another PSII inhibitor is 3-(3,4-dichlorophenyl)-1,1dimethylurea (DCMU) [26]. DCMU can block electron transfer between the primary quinone electron accepter $\left(Q_{A}\right)$ and secondary quinone electron accepter $\left(Q_{B}\right)$ on the reducing side of PSII [26]. This interrupts the photosynthetic electron transport chain in photosynthesis and thus reduces the generation of $\mathrm{O}_{2}$ from splitting water molecules via PSII. DCMU has been shown to inhibit PSII activity in cyanobacteria Aphanocapsa 6308 [27], Nostoc sp., and Lyngbya sp. [13] and green alga Scenedesmus quadricauda [28]. DCMU influences other cellular processes, such as cyclic phosphorylation, chlorophyll synthesis, and fatty acid synthesis [29]. In previous reports, $\mathrm{H}_{2}$ production of the cyanobacteria Anabaena spp. strains CA and $1 \mathrm{~F}$ [30], Anabaena cylindrica [31], Anabaena 7120 [32], and the green alga P. helgolandica var. tsingtaoensis [22] was increased in the presence of DCMU under illumination. In addition, DCMU caused the inhibition of dark respiration in cyanobacteria Plectonema boryanum [33] and Anabaena flos-aquae [34].

The goal of the present study was to investigate the effects of the PSII inhibitors CCCP and DCMU on $\mathrm{H}_{2}$ production by the cyanobacterium $A$. halophytica. The data will improve our understanding of the functional relationships between $\mathrm{H}_{2}$ metabolism and photosynthetic and respiration efficiency. The knowledge gained in this study will be useful to enhance $\mathrm{H}_{2}$ production by $A$. halophytica under light or dark conditions by a use of the effective PSII inhibitors, DCMU and CCCP. $\mathrm{H}_{2}$ evolution by this cyanobacterium might be one of the most promising ways to produce alternative clean energy fuel in the future.

\section{Materials and Methods}

2.1. Growth Conditions. A. halophytica was cultivated in a 250-mL Erlenmeyer flask containing $100 \mathrm{~mL}$ of BG11 medium (pH 7.4) [35] supplemented with Turk Island salt solution [36]. The initial cell concentration was adjusted to an optical density of approximately 0.1 at $730 \mathrm{~nm}$. Cells were shaken at $120 \mathrm{rpm}$ at $30^{\circ} \mathrm{C}$ under a cool white light intensity of $30 \mu \mathrm{mol}$ photons $\mathrm{m}^{-2} \mathrm{~s}^{-1}$ for 7 days.

2.2. Application of CCCP and DCMU. After the 7 days of growth, $100 \mathrm{~mL}$ of $A$. halophytica cells was harvested by centrifugation at $8,000 \times \mathrm{g}$ at $4^{\circ} \mathrm{C}$ for $10 \mathrm{~min}$. The cell pellet was washed twice and resuspended in $100 \mathrm{~mL}$ of nitrogendeprived BG11 (BG11 ${ }_{0}$ ) supplemented with Turk Island salt solution. The cells in suspension were transferred to a 250 $\mathrm{mL}$ Erlenmeyer flask and incubated on a rotary shaker at $120 \mathrm{rpm}$ at $30^{\circ} \mathrm{C}$ under $30 \mu \mathrm{mol}$ photons $\mathrm{m}^{-2} \mathrm{~s}^{-1}$ for $24 \mathrm{~h}$. Cells were subsequently harvested by centrifugation and resuspended in $5 \mathrm{~mL}$ of BG11 ${ }_{0}$ supplemented with Turk Island salt solution. Next, a 5-mL volume of the cells in suspension was transferred to a $10-\mathrm{mL}$ glass vial. CCCP and DCMU were subsequently added into the cell suspension with final concentrations of $0-5 \mu \mathrm{M}$ and $0-250 \mu \mathrm{M}$, respectively. The vials were sealed with a rubber stopper with an aluminum rim and incubated at $30^{\circ} \mathrm{C}$ under $30 \mu \mathrm{mol}$ photons $\mathrm{m}^{-2} \mathrm{~s}^{-1}$ for $2 \mathrm{~h}$. The vials were subsequently purged with argon gas for $10 \mathrm{~min}$ to establish anaerobic conditions. The vials were further incubated under light at $30^{\circ} \mathrm{C}$. Aliquots of cells in suspension after incubation for 2, 24, 48, 72, and $96 \mathrm{~h}$ were collected for analysis of cell and chlorophyll concentrations. Bidirectional hydrogenase activity, photosynthetic efficiency of PSII by chlorophyll fluorescence measurement, and dark respiration rate were analyzed after the cells were exposed to the light for $2 \mathrm{~h} . \mathrm{H}_{2}$ production was analyzed after the cells were placed in both light and dark conditions for $2 \mathrm{~h}$.

\subsection{Measurement of Cell Concentration and Chlorophyll-} a Concentration. The cell concentration of A. halophytica was analyzed using a hemocytometer under a microscope (Nikon Eclipse Ci-L, Japan). To analyze the chlorophylla concentration, $1 \mathrm{~mL}$ of a cell culture was harvested by centrifugation at $8,000 \mathrm{xg}$ at $4^{\circ} \mathrm{C}$ for $10 \mathrm{~min}$. A 1 - $\mathrm{mL}$ volume of $90 \%(\mathrm{v} / \mathrm{v})$ methanol was added to the cell pellet and mixed by vortexing. The mixture was incubated at $25^{\circ} \mathrm{C}$ in the dark for $1 \mathrm{~h}$. The chlorophyll-a content was determined by measuring the absorbance of the extract at $665 \mathrm{~nm}$ by spectrophotometer [37].

2.4. Measurement of $\mathrm{H}_{2}$ Production. $\mathrm{H}_{2}$ concentration in $500 \mu \mathrm{L}$ of headspace gas was analyzed by gas chromatograph (Hewlett-Packard HP5890A, Japan) with a molecular sieve $5^{\circ} \mathrm{A}, 60 / 80$ mesh packed column using a thermal conductivity 
detector under previously described conditions [6]. The $\mathrm{H}_{2}$ production rate was calculated as a term of $\mu \mathrm{mol} \mathrm{H}_{2} \mathrm{~g}^{-1}$ dry weight $\mathrm{h}^{-1}$.

2.5. Measurement of Bidirectional Hydrogenase Activity. The bidirectional hydrogenase activity in the A. halophytica sample was determined after cells were incubated with various concentrations of CCCP and DCMU under the light for $2 \mathrm{~h}$. Bidirectional hydrogenase activity was measured in the presence of dithionite-reduced methyl viologen. The assay contained $1 \mathrm{~mL}$ of cells in suspension and $1 \mathrm{~mL}$ of $25 \mathrm{mM}$ phosphate buffer ( $\mathrm{pH} 7.0$ ) containing $2.5 \mathrm{mM}$ methyl viologen and $10 \mathrm{mM}$ sodium dithionite [7]. The reaction mixture was incubated under dark anaerobic conditions at $25^{\circ} \mathrm{C}$ for $15 \mathrm{~min}$ before $\mathrm{H}_{2}$ production was measured using gas chromatography, under previously described conditions [7]. Bidirectional hydrogenase activity was calculated in terms of $\mu \mathrm{mol} \mathrm{H}_{2} \mathrm{~g}^{-1}$ dry weight $\min ^{-1}$.

2.6. Dark Respiration Rate Measurement. The dark respiration rate was monitored at $25^{\circ} \mathrm{C}$ using a Clark-type oxygen electrode (Hansatech, UK). First, $2 \mathrm{~mL}$ of cells in suspension was added to the chamber and illuminated under $300 \mu \mathrm{mol}$ photons $\mathrm{m}^{-2} \mathrm{~s}^{-1}$ of white light until the $\mathrm{O}_{2}$ concentration was constant. Then, the respiratory rate was measured as $\mathrm{O}_{2}$ consumption in the dark for $15 \mathrm{~min}$. The dark respiration rate was calculated as a term of $\mu \mathrm{mol} \mathrm{O}_{2} \mathrm{~g}^{-1}$ dry weight $\mathrm{min}^{-1}$.

2.7. Fluorescence Emission Spectra Measurement. Chlorophyll fluorescence emission spectra were determined at room temperature by spectrofluorometer (Jasco, Model FP-6300, Japan). First, $1 \mathrm{~mL}$ of cyanobacteria treated and not treated with CCCP and DCMU was exposed to light at 2,000 $\mu \mathrm{mol}$ photons $\mathrm{m}^{-2} \mathrm{~s}^{-1}$ at room temperature for $10 \mathrm{~min}$ prior to chlorophyll fluorescence measurement, following Joshua et al. [38]. The chlorophyll fluorescence measurement was carried out using the excitation wavelength at $437 \mathrm{~nm}$.

2.8. Statistical Data Analysis. The data in this study were statistically compared using a one-way ANOVA with Duncan's post hoc test. Differences between means were considered significant at $0.05(p<0.05)$. Data were analyzed using IBM SPSS statistic 23 (IBM Corp., USA).

\section{Results}

3.1. Effects of CCCP and DCMU on Cell and Chlorophylla Concentrations under N-Deprivation. After A. halophytica cells were incubated in a nitrogen-deprived medium containing various concentrations of CCCP $(0-5 \mu \mathrm{M})$ and DCMU $(0-250 \mu \mathrm{M})$ under light for $2,24,48,72$, and $96 \mathrm{~h}$, cell and chlorophyll-a concentrations were measured. The concentrations of both decreased after the cells were incubated in BG11 ${ }_{0}$ containing CCCP or DCMU. Both concentrations slightly decreased in the first $2 \mathrm{~h}$ of incubation and continued to decrease to $96 \mathrm{~h}$ of incubation (Figure 1). Higher concentrations and longer incubation times of CCCP and
DCMU led to an obvious decrease in the cell and chlorophylla concentrations of A. halophytica (Figure 1).

3.2. Effects of CCCP and DCMU on $\mathrm{H}_{2}$ Production. A. halophytica cells were treated with various concentrations of CCCP $(0-5 \mu \mathrm{M})$ and DCMU $(0-250 \mu \mathrm{M})$ and incubated under light at $30^{\circ} \mathrm{C}$ for $2 \mathrm{~h}$ before $\mathrm{H}_{2}$ was measured under dark and light anaerobic conditions. The cells that were incubated in the dark, with or without CCCP and DCMU treatment, generated $\mathrm{H}_{2}$ at a higher rate than did those incubated under the light (Figure 2). For cells treated with CCCP, the $\mathrm{H}_{2}$ production rates, under conditions of both illumination and darkness, were significantly increased, corresponding with the higher concentrations of CCCP (Figures 2(a) and 2(b)). However, the highest concentration of CCCP $(5 \mu \mathrm{M})$ resulted in the lowest $\mathrm{H}_{2}$ production rates (Figures 2(a) and 2(b)). The highest $\mathrm{H}_{2}$ production rates of $2.26 \pm 0.24$ and $39.50 \pm 2.13 \mu \mathrm{mol} \mathrm{H}_{2} \mathrm{~g}^{-1}$ dry weight $\mathrm{h}^{-1}$ were found in $A$. halophytica cells treated with $0.5 \mu \mathrm{M}$ CCCP under light and dark conditions (Figures 2 (a) and 2(b)). These $\mathrm{H}_{2}$ production rates were approximately threefold higher than those of cells without CCCP treatment.

In the presence of DCMU, A. halophytica showed a higher $\mathrm{H}_{2}$ production rate only when cells were incubated under light (Figure 2(c)). Dark fermentative $\mathrm{H}_{2}$ production was not increased in cells treated with all concentrations of DCMU (Figure 2(d)). Interestingly, in the presence of 250 $\mu \mathrm{M}$ DCMU, dark fermentative $\mathrm{H}_{2}$ production was obviously decreased and was lower than that in cells without DCMU treatment (Figure $2(\mathrm{~d})$ ). The highest $\mathrm{H}_{2}$ production rates of $3.63 \pm 0.26$ and $16.19 \pm 1.32 \mu \mathrm{mol} \mathrm{H}_{2} \mathrm{~g}^{-1}$ dry weight $\mathrm{h}^{-1}$ were found in A. halophytica cells treated with $50 \mu \mathrm{M}$ DCMU under light and dark conditions (Figures 2(c) and 2(d)). The results indicated that CCCP increased the $\mathrm{H}_{2}$ production rate under light and dark conditions and that DCMU increased it only under the light.

\subsection{Effects of CCCP and DCMU on Bidirectional Hydrogenase} Activity. To determine whether an increase in $\mathrm{H}_{2}$ production after CCCP and DCMU treatment resulted from increased bidirectional hydrogenase activity, A. halophytica cells were treated or not treated with CCCP or DCMU and incubated under the light for $2 \mathrm{~h}$ before bidirectional hydrogenase activity was measured. The results showed that bidirectional hydrogenase activity was higher when cells were treated with higher CCCP and DCMU concentrations. The highest bidirectional hydrogenase activity levels of $27.32 \pm 2.73$ and $22.58 \pm 2.15 \mu \mathrm{mol} \mathrm{H} \mathrm{g}^{-1}$ dry weight $\min ^{-1}$ were found in cells treated with $0.5 \mu \mathrm{M}$ CCCP and $50 \mu \mathrm{M}$ DCMU, respectively (Figures $3(\mathrm{a}$ ) and 3(b)). When CCCP and DCMU concentrations exceeded these concentrations, the bidirectional hydrogenase activity level decreased (Figures 3(a) and 3(b)). As expected, bidirectional hydrogenase activities were related to $\mathrm{H}_{2}$ production rates (Figures 2 and 3).

3.4. Effect of CCCP and DCMU on Chlorophyll Fluorescence. Chlorophyll fluorescence emission spectra of $A$. halophytica cells treated with various concentrations of CCCP and 


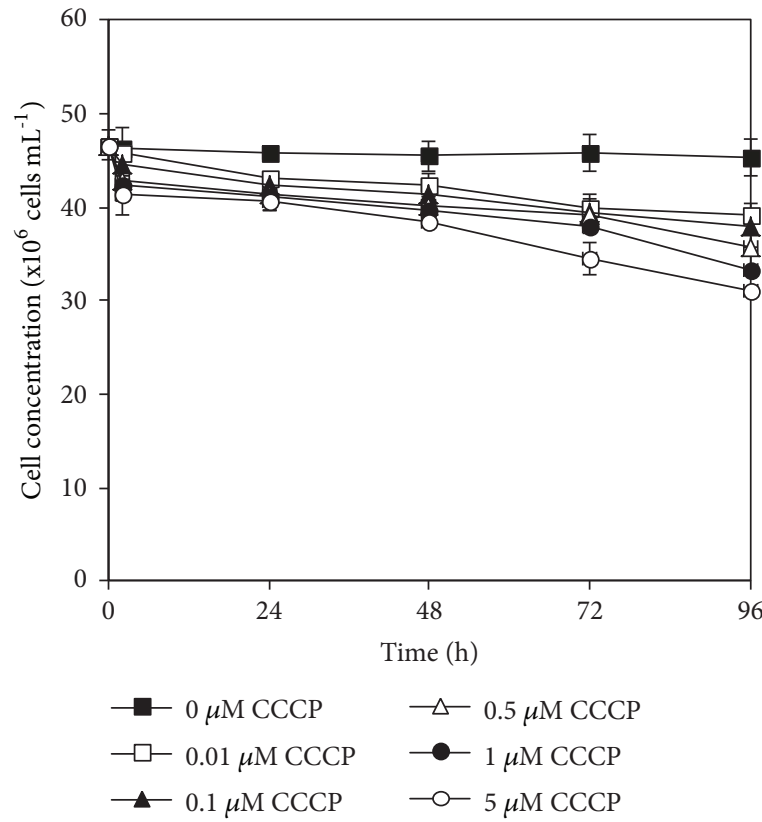

(a)

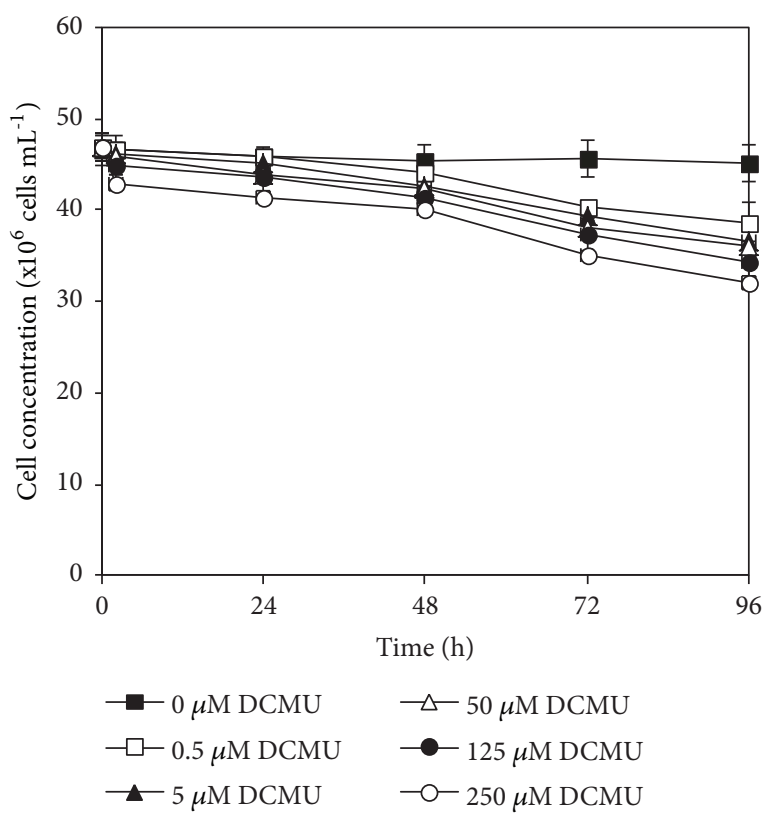

(c)

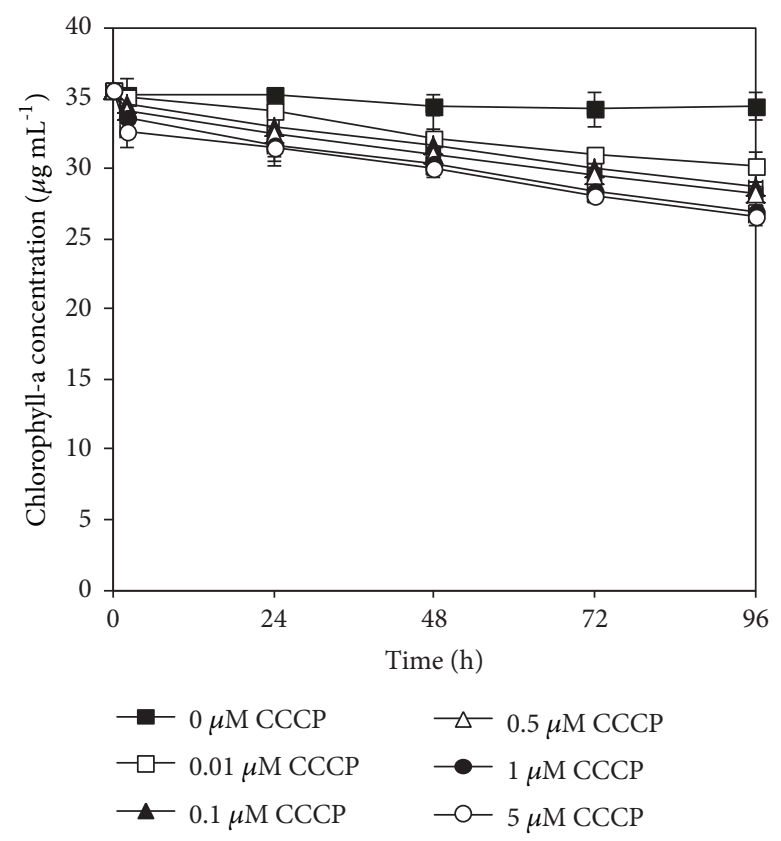

(b)

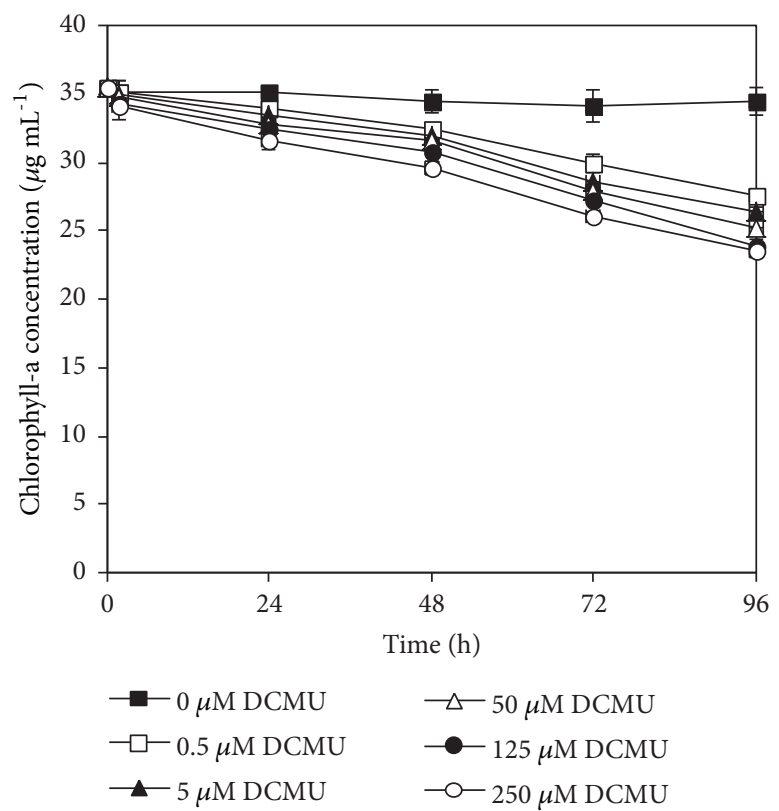

(d)

FIGURE 1: Effects of various concentrations of carbonyl cyanide m-chlorophenyl hydrazone (CCCP) and 3-(3,4-dichlorophenyl)-1,1dimethylurea (DCMU) on cell concentrations $(\mathrm{a}, \mathrm{c})$ and chlorophyll-a concentrations $(\mathrm{b}, \mathrm{d})$ of Aphanothece halophytica after various incubation durations.

DCMU under the light for $2 \mathrm{~h}$ were measured. The results showed that the chlorophyll fluorescence emission spectra of A. halophytica cells treated with higher concentrations of CCCP or DCMU were significantly lower than those that were not treated (Figure 4), suggesting that these inhibitors could inhibit PSII efficiency, leading to a decrease in the $\mathrm{O}_{2}$ level in vials (data not shown), an increase in bidirectional hydrogenase activity (Figure 3), and an increase in $\mathrm{H}_{2}$ production rate (Figure 2).
3.5. Effects of CCCP and DCMU on Dark Respiration. The measurement of dark respiration rate was performed in $A$. halophytica cells after they were treated or not treated with CCCP or DCMU. Cells treated with $0.01-1 \mu \mathrm{M}$ CCCP showed higher dark respiration rates than those that were not treated with CCCP (Figure 5(a)). The highest dark respiration rate of $335.30 \pm 3.32 \mu \mathrm{mol} \mathrm{O} \mathrm{g}^{-1}$ dry weight $\mathrm{min}^{-1}$ was found in cells that were treated with $0.5 \mu \mathrm{M}$ CCCP, and the lowest dark respiration rate was found in cells treated with $5 \mu \mathrm{M}$ 


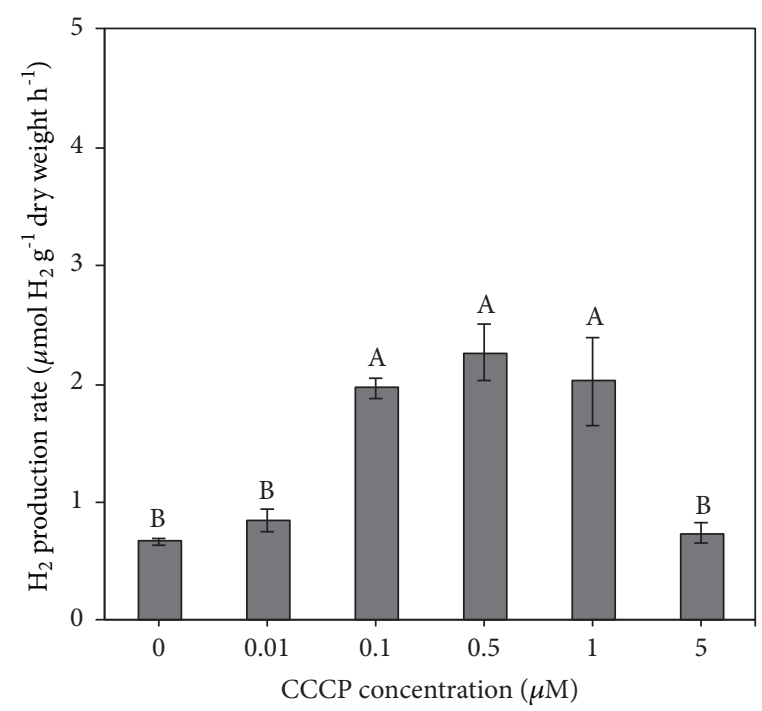

(a)

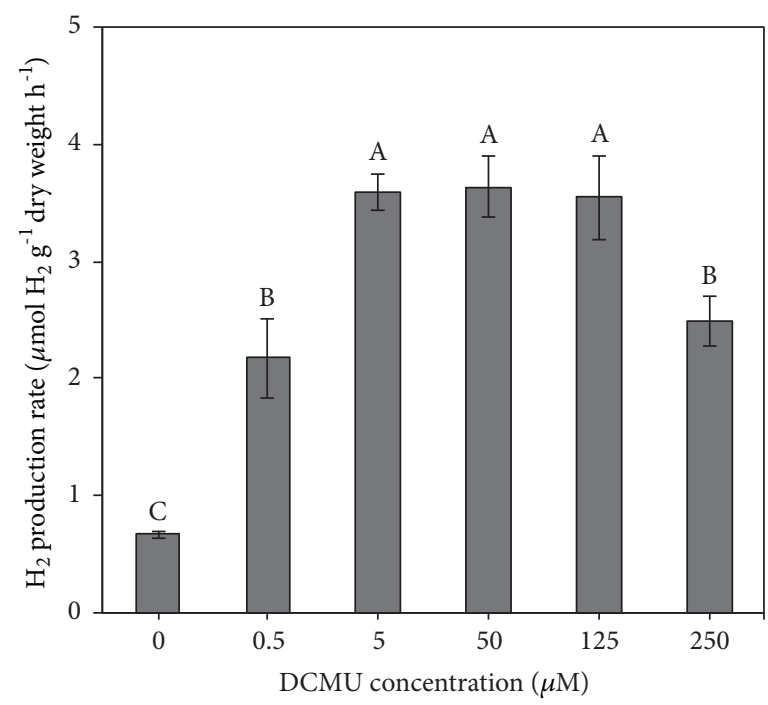

(c)

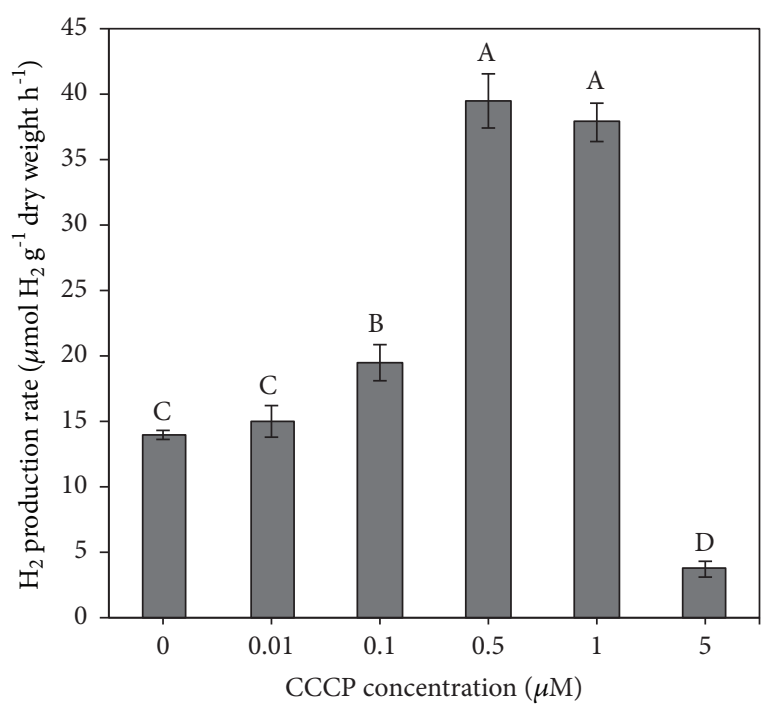

(b)

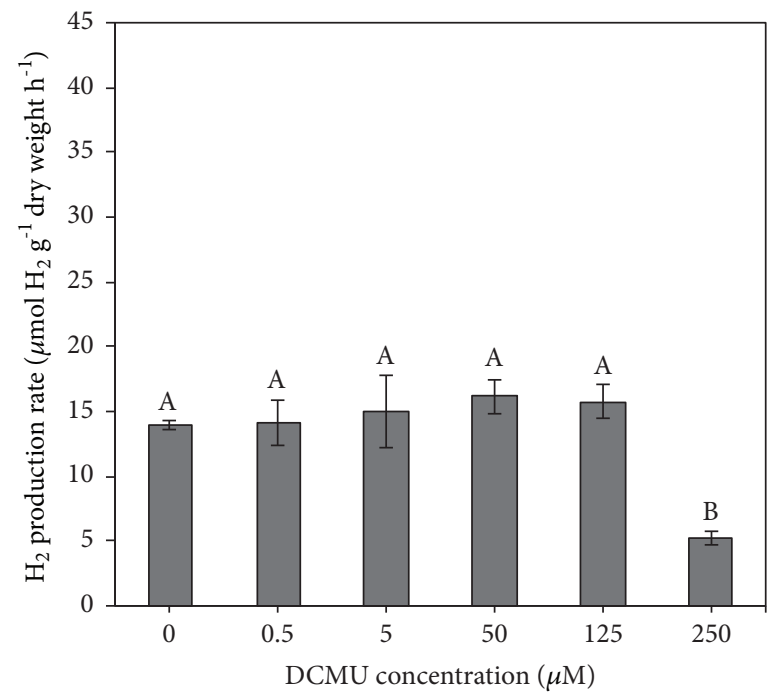

(d)

FIGURE 2: Effects of various concentrations of carbonyl cyanide m-chlorophenyl hydrazone (CCCP) and 3-(3,4-dichlorophenyl)-1,1dimethylurea (DCMU) on $\mathrm{H}_{2}$ production rate by Aphanothece halophytica after 2 hours of incubation under the light (a, c) and under darkness $(b, d)$. Data are means $\pm S D(n=3)$. Different letters above columns indicate a significant difference according to Duncan's multiple range test at $p<0.05$.

CCCP (Figure 5(a)). DCMU concentrations higher than 0.5 $\mu \mathrm{M}$ reduced the dark respiration rate of $A$. halophytica cells (Figure 5(b)).

\section{Discussion}

4.1. Effects of CCCP and DCMU on Cell Inhibition. The treatment of $A$. halophytica cells with CCCP led to a reduction in cell concentration (Figure 1(a)) and chlorophyll-a concentration (Figure 1(b)), especially in cells that received high concentrations of CCCP over long-term incubations (Figures $1(\mathrm{a})$ and $1(\mathrm{~b})$ ). In the absence of CCCP, cells did not show any changes in the cell and chlorophyll-a concentrations. The cell and chlorophyll-a concentrations also did not increase because all cells were incubated in $\mathrm{BGll}_{0}$ lacking in $\mathrm{NaNO}_{3}$, which is a nitrogen source for cyanobacterial growth. CCCP, which functions as the PSII inhibitor, inhibited the rate of electron flow through the photosynthetic electron transport chain in the thylakoid membrane of cyanobacterial cells [13]. Consequently, cell and chlorophyll concentrations in A. halophytica were decreased. These results were consistent with previous studies showing a decrease in the optical density and cell concentration of other microalgae [39, 40]. In Synechococcus sp., the optical density at $750 \mathrm{~nm}$ and viable cell count were decreased after the addition of $10 \mu \mathrm{M}$ CCCP [39]. The unicellular green alga C. reinhardtii showed MICs at 8.5 and $14.6 \mu \mathrm{M}$ for CCCP under heterotrophic and photoautotrophic growth conditions, respectively [40]. In 


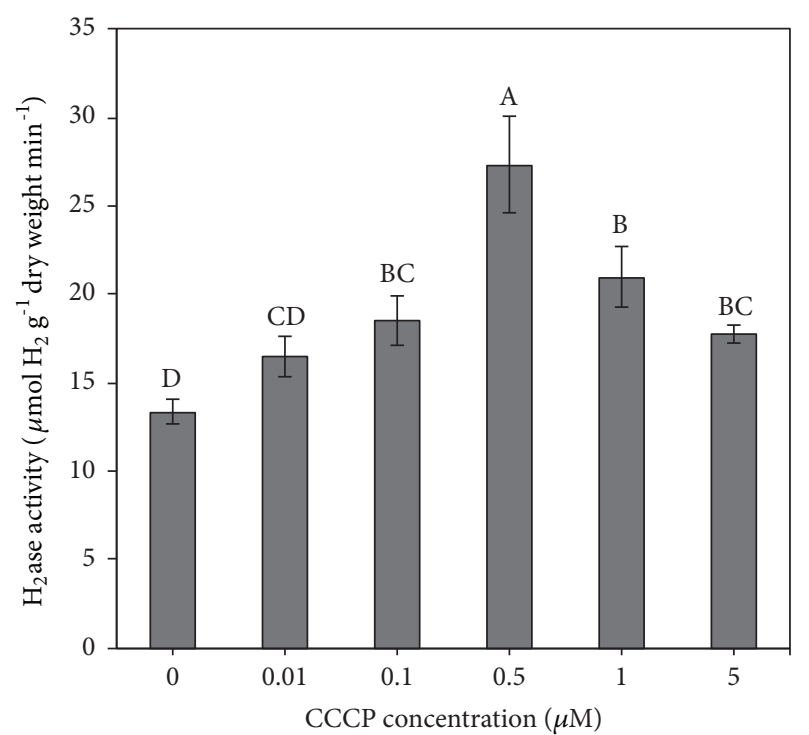

(a)

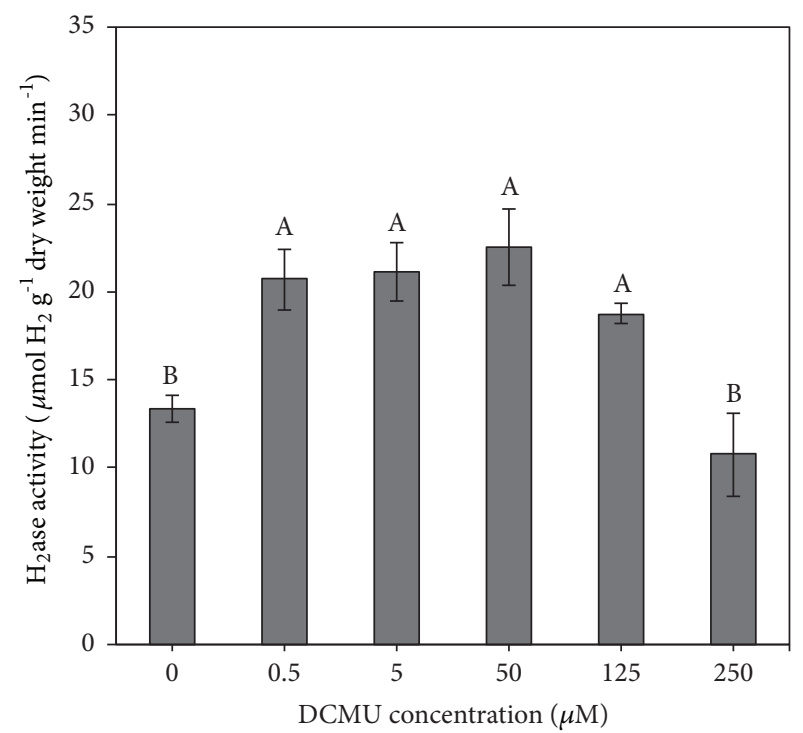

(b)

FIGURE 3: Effects of various concentrations of carbonyl cyanide m-chlorophenyl hydrazone (CCCP) (a) and 3-(3,4-dichlorophenyl)-1,1dimethylurea (DCMU) (b) on bidirectional hydrogenase of Aphanothece halophytica after 2 hours of treatment under illumination. Data are means \pm SD $(n=3)$. Different letters above columns indicate a significant difference according to Duncan's multiple range test at $p<0.05$.

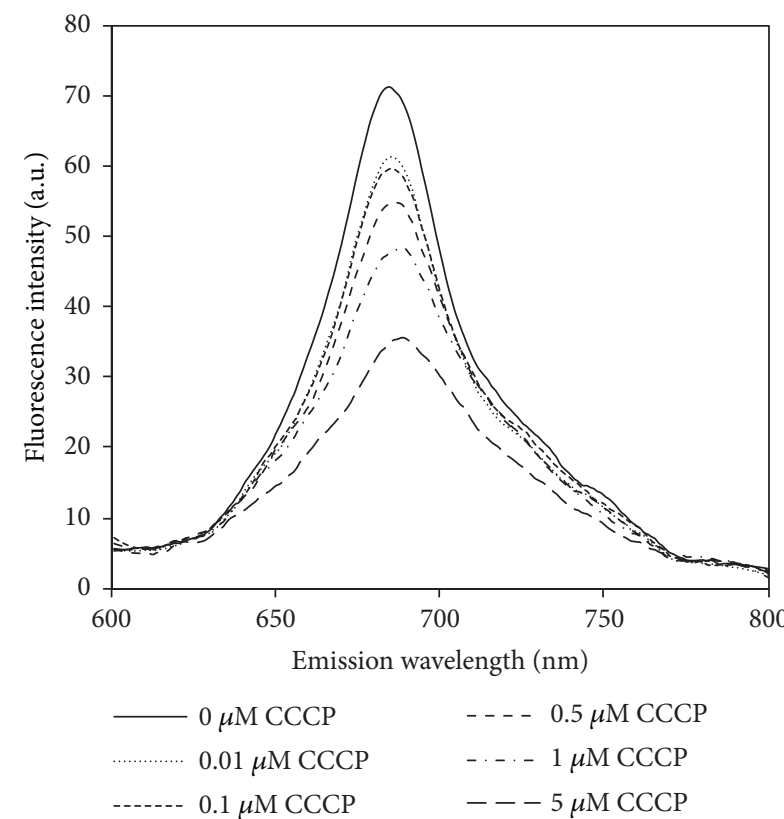

(a)

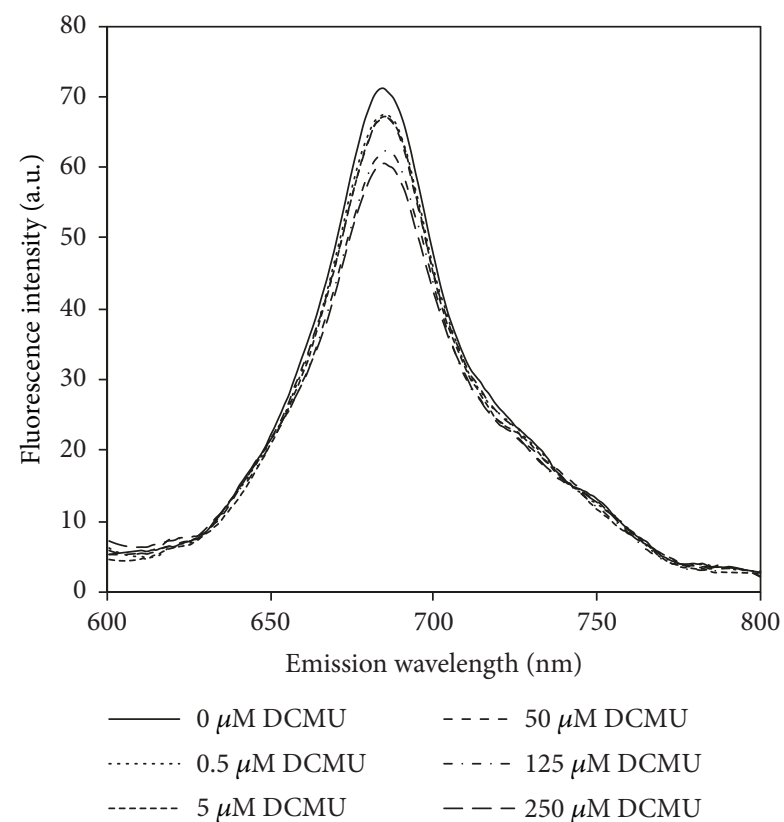

(b)

FIGURE 4: Fluorescence emission spectra of Aphanothece halophytica incubated in BG11 (pH 7.4) supplemented with Turk Island salt solution containing various concentrations of carbonyl cyanide m-chlorophenyl hydrazone (CCCP) (a) and 3-(3,4-dichlorophenyl)-1,1-dimethylurea (DCMU) (b) after 2 hours of treatment under illumination.

case of chlorophyll content, the green algae $P$. helgolandica var. tsingtaoensis and $C$. reinhardtii showed a decrease in chlorophyll content when cell cultures were treated with 15 $\mu \mathrm{M}$ CCCP $[19,22]$.

The treatment of A. halophytica with DCMU also caused a reduction in cell concentration (Figure 1(c)) and chlorophyll-a concentration (Figure 1(d)). DCMU, similar to CCCP, is responsible for inhibition of photosynthetic activity; therefore, DCMU treatment inhibited cell growth and chlorophyll concentrations as shown in Figures 1(c) and $1(\mathrm{~d})$. These results agreed with previous studies. In Synechocystis sp. PCC 6803, the optical density at $730 \mathrm{~nm}$ was 


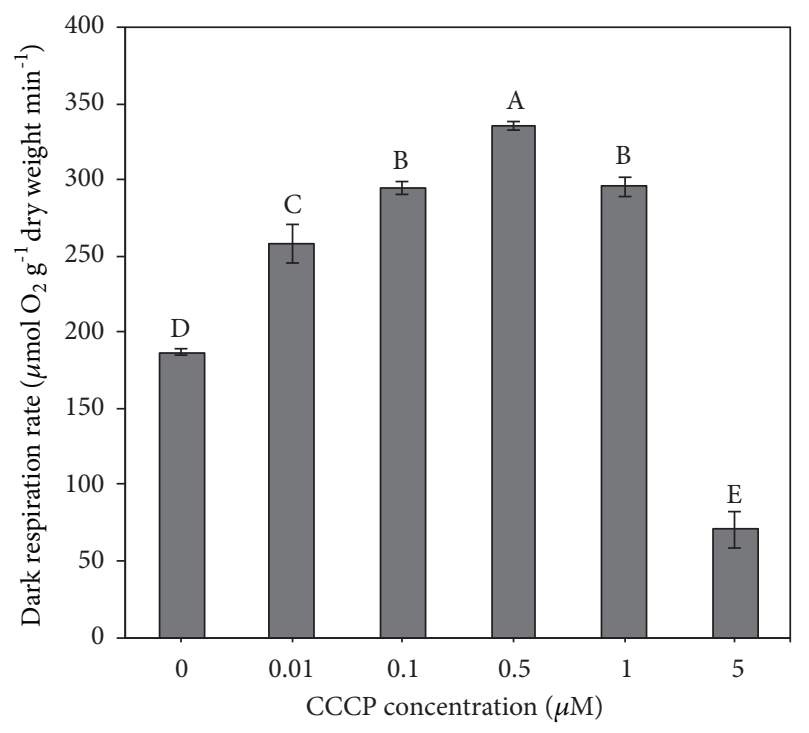

(a)

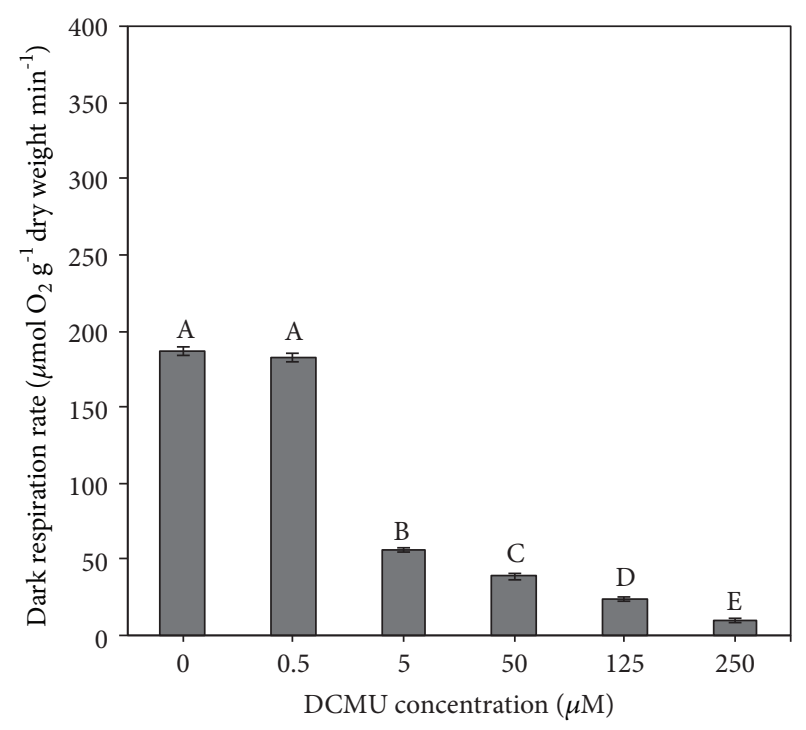

(b)

FIGURE 5: Effects of various concentrations of carbonyl cyanide m-chlorophenyl hydrazone (CCCP) (a) and 3-(3,4-dichlorophenyl)-1,1dimethylurea (DCMU) (b) on dark respiration rate of Aphanothece halophytica after 2 hours of treatment under illumination. Data are means \pm SD $(n=3)$. Different letters on columns indicate a significant difference according to Duncan's multiple range test at $p<0.05$.

decreased in the presence of $0.1 \mu \mathrm{M} \mathrm{DCMU}$ [41]. DCMU at 0.1 $\mu \mathrm{M}$ caused a significant reduction in the growth of colonies of algae Eudorina elegans [42] and Nannochloropsis [43]. In the presence of DCMU, the chlorophyll concentrations of the $\mathrm{N}_{2}$ fixing cyanobacteria Nostoc sp. G3 and A. variabilis obviously decreased $[44,45]$. The results of the present study suggested that high concentrations of CCCP and DCMU and long-term incubation caused cell toxicity and death.

4.2. $\mathrm{H}_{2}$ Production of A. halophytica under Light and Dark Conditions. $\mathrm{H}_{2}$ production rates by $A$. halophytica cells incubated in the dark were higher than those incubated under the light, in the presence or absence of inhibitors (Figure 2), indicating that light can inhibit $\mathrm{H}_{2}$ production by $A$. halophytica. A. halophytica cells under the light produced more $\mathrm{O}_{2}$ than did those in the dark (data not shown) due to the generation of $\mathrm{O}_{2}$ from the splitting of water molecules via PSII activity in the thylakoid membrane. $\mathrm{O}_{2}$ inhibits the bidirectional hydrogenase activity of $A$. halophytica cells, resulting in lower $\mathrm{H}_{2}$ production. In the dark, $A$. halophytica cells had reduced photolysis but engaged in dark respiration, leading to a lower $\mathrm{O}_{2}$ concentration in the system and enhanced $\mathrm{H}_{2}$ production. Moreover, nitrogen-deprived cells of $A$. halophytica were able to generate more $\mathrm{H}_{2}$ from electrons acquired through the degradation of stored glycogen under dark, anaerobic conditions than from photosynthesis under light conditions [6-8].

\subsection{Effects of CCCP on $\mathrm{H}_{2}$ Production, Bidirectional Hydro-} genase Activity, Photosynthetic Activity, and Dark Respiration. The CCCP-treated A. halophytica showed significantly higher $\mathrm{H}_{2}$ production under both light and dark conditions than CCCP-untreated cells. The highest $\mathrm{H}_{2}$ production rates of $2.26 \pm 0.24$ and $39.50 \pm 2.13 \mu \mathrm{mol} \mathrm{H}_{2} \mathrm{~g}^{-1}$ dry weight $\mathrm{h}^{-1}$ were found in cultures treated with $0.5 \mu \mathrm{M}$ CCCP and incubated under light and dark conditions, respectively (Figures 2(a) and 2(b)). These $\mathrm{H}_{2}$ production rates were approximately threefold higher than those in the absence of CCCP. CCCPtreated cells also produced less $\mathrm{O}_{2}$, as measured in the gas (data not shown). The lower $\mathrm{O}_{2}$ concentration in the glass vial caused increased bidirectional hydrogenase activity, as shown in Figure 3(a), and increased the $\mathrm{H}_{2}$ production rate (Figure 2). Our results agree with previous studies showing that $\mathrm{H}_{2}$ production rates of the cyanobacteria $O$. chalybea and Synechocystis sp. PCC 6803 treated with CCCP were higher than those of untreated cells [18]. In green algae, $\mathrm{H}_{2}$ production by $C$. reinhardtii, $P$. subcordiformis, and Tetraselmis subcordiformis was also increased in CCCPtreated cells $[17,19,46]$.

CCCP-treated A. halophytica cells showed an increase in the $\mathrm{H}_{2}$ production rate under dark conditions (Figure 2(b)). This enhancement most likely was not due to decreased PSII activity by CCCP, but to the inhibition of oxidative phosphorylation by another effect of CCCP as an uncoupler agent [33]. In green algae, CCCP inhibits the flow of electrons in the electron transport chain and promotes the pumping of protons in the oxidative phosphorylation reaction by transporting protons across the thylakoid membrane [20,47]. As a result, the activity of ATP synthase is reduced, and ATP synthesis is inhibited. The released or excess protons and electrons could be reduced by bidirectional hydrogenase to generate $\mathrm{H}_{2}$ [17].

To confirm the effects of CCCP on $\mathrm{H}_{2}$ production by A. halophytica, bidirectional hydrogenase activity, photosynthetic activity, and dark respiration rate were measured. A treatment of $0.5 \mu \mathrm{M}$ CCCP produced the highest bidirectional hydrogenase activity level (Figure 3(a)), indicating that concentration of CCCP at $0.5 \mu \mathrm{M}$ is optimal for promoting 
bidirectional hydrogenase activity in A. halophytica. In a previous study, a treatment with $10 \mu \mathrm{M}$ CCCP could increase bidirectional hydrogenase activity in Anabaena siamensis TISTR 8012 [48]. Therefore, the CCCP concentration influencing hydrogenase activity is species-dependent. However, the chlorophyll fluorescence intensity of A. halophytica cells decreased as CCCP concentrations increased (Figure 4(a)). Evidently, CCCP inhibited photosystem II activity, contributing to the lower chlorophyll fluorescence, as shown in Figure 4(a). Moreover, CCCP could inhibit ATP synthesis from working as an uncoupler of oxidative phosphorylation and subsequently increase the respiration rate, as shown in Figure 5(a). The decrease in $\mathrm{O}_{2}$ photoevolution, together with the increase in $\mathrm{O}_{2}$ consumption, promoted a low level of $\mathrm{O}_{2}$ in the system, which is favorable for bidirectional hydrogenase activity. Our results were similar to previous results reported in many cyanobacterial and green algal strains, demonstrating that CCCP reduced PSII photochemical activity $[17,19,21$, 46,49 ] and enhanced the rate of dark respiration [23]. It has been reported that the rate of dark respiration was markedly enhanced by addition of 5 and $10 \mu \mathrm{M}$ CCCP to the cultures of A. variabilis [23] and A. nidulans [24]. In C. reinhardtii, CCCP at $2.5 \mu \mathrm{M}$ increased the dark respiration rate by $40 \%$ without influencing photosynthesis [25]. However, in this study the effect of CCCP on the dark respiration rate in A. halophytica was dependent on the CCCP concentration. These data on the stimulation of $\mathrm{H}_{2}$ photoevolution and dark fermentative $\mathrm{H}_{2}$ production by CCCP treatment may be used to optimize $\mathrm{H}_{2}$ production by $A$. halophytica in the future.

\subsection{Effects of DCMU on $\mathrm{H}_{2}$ Production, Bidirectional Hydro-} genase Activity, Dark Respiration, and Photosynthetic Activity. DCMU-treated A. halophytica produced $\mathrm{H}_{2}$ at a significantly higher rate than did DCMU-untreated cells under light conditions (Figure 2(c)) but not under darkness (Figure 2(d)). Evidently, DCMU functioned as a PSII inhibitor in the light, leading to the reduction of $\mathrm{O}_{2}$ photoevolution from photolysis. Therefore, the decreased $\mathrm{O}_{2}$ level caused an increase of $\mathrm{H}_{2}$ production. These results were consistent with the previous results described for CCCP-treated cells. However, under dark conditions, the cyanobacterial cells could not perform photosynthesis and thus were unable to generate $\mathrm{O}_{2}$. Therefore, DCMU might not inactivate PSII activity under darkness, resulting in a constant $\mathrm{H}_{2}$ production rate compared with the untreated cells. In addition, it is likely that DCMU could not promote dark fermentative $\mathrm{H}_{2}$ production by $A$. halophytica. These results contrasted with those of studies in Synechocystis sp. PCC 6803, which reported higher $\mathrm{H}_{2}$ production in the presence of $75 \mu \mathrm{M}$ DCMU under dark and anaerobic conditions [50,51].

Under light conditions, the $\mathrm{H}_{2}$ production rate of $50 \mu \mathrm{M}$ DCMU-treated A. halophytica cells was threefold higher than that of untreated cells (Figure 2(c)). This high rate resulted from the highest observed bidirectional hydrogenase activity in the present study, recorded in $50 \mu \mathrm{M}$ DCMU-treated cells (Figure 3(b)). This result was consistent with the previous study showing that the highest bidirectional hydrogenase activity of A. siamensis TISTR 8012 was obtained when treating cells with $50 \mu \mathrm{M}$ DCMU under nitrogen deprivation
[48]. In this study, it could be explained that the increased hydrogenase activity resulted from a decrease in the chlorophyll fluorescence intensity (Figure 4(b)) and/or the dark respiration rate (Figure 5(b)), indicating that DCMU caused the inhibition of both dark respiration and PSII activity. Our findings that $\mathrm{H}_{2}$ production increased after treatment with DCMU agreed with previous studies on cyanobacteria and green algae. In the cyanobacterium A. cylindrica, $\mathrm{H}_{2}$ production was improved in cells incubated with DCMU, due to the low level of $\mathrm{O}_{2}$ [31]. $\mathrm{H}_{2}$ photoevolution also increased in cells of a new marine green alga, P. helgolandica var. tsingtaoensis which were treated with DCMU, as PSII photochemical activity during illumination was completely inhibited by DCMU [22]. The similar result of DCMU inhibition on the photosynthetic electron transport system was reported in the cyanobacteria Aphanocapsa 6308 [27], A. nidulans [52], and $A$. siamensis TISTR 8012 [48]. In contrast to CCCP result, DCMU treatment did not show an enhanced rate of respiration in A. halophytica but showed a significant decrease in respiration rate, especially with high DCMU concentrations (Figure 5(b)), suggesting that DCMU and CCCP possess different functions involved in the respiratory mechanism. Similar results were also found in A. flos-aquae [34] and Chlorella sp. [53] showing an inhibition of DCMU in respiration rates in the dark.

In the present study, high concentration of CCCP (5 $\mu \mathrm{M})$ and DCMU $(250 \mu \mathrm{M})$ induced a significant decrease of $\mathrm{H}_{2}$ production (Figure 2) due to the toxicity of CCCP and DCMU to A. halophytica cells. These results were confirmed by other experiments showing that too high concentrations of CCCP and DCMU reduced cell and chlorophyll concentrations (Figure 1), the bidirectional hydrogenase activity level (Figure 3), chlorophyll fluorescence intensities (Figure 4), and dark respiration rates (Figure 5).

\section{Conclusions}

Previous studies reported that, due to the limitation of $\mathrm{O}_{2}$ on bidirectional hydrogenase activity in the cyanobacterium $A$. halophytica, a very low level of $\mathrm{H}_{2}$ was detected after cells were exposed to illumination. In the present study, the well-known photosystem II inhibitors CCCP and DCMU were added to A. halophytica samples in an effort to enhance $\mathrm{H}_{2}$ production. Both CCCP and DCMU enhanced $\mathrm{H}_{2}$ production of $A$. halophytica under light conditions, whereas only CCCP enhanced $\mathrm{H}_{2}$ production under darkness. CCCP and DCMU functioned as PSII inhibitors during illumination, resulting in a decrease of chlorophyll fluorescence and $\mathrm{O}_{2}$ production in a glass vial. As a result, bidirectional hydrogenase activity was increased and $\mathrm{H}_{2}$ production was increased. In addition, CCCP functioned as an uncoupling agent of oxidative phosphorylation, decreasing both proton pumping and ATP synthesis, which resulted in an increase in the respiration rate. This effect helped increase $\mathrm{H}_{2}$ production after CCCP treatment under darkness. Our data showed that CCCP can increase $\mathrm{H}_{2}$ production by $A$. halophytica under both light and dark conditions. However, high concentration and longterm incubation of CCCP led to high cell toxicity. Since A. 
halophytica can grow in natural seawater supplemented with $1.76 \mathrm{mM} \mathrm{NaNO}_{3}$ [7], it would be useful if this cyanobacterium grown in natural seawater will produce long-term of $\mathrm{H}_{2}$ photohydrogen by using PSII inhibitors. This study needs further investigation.

\section{Data Availability}

The data used to support the findings of this study are included within the article.

\section{Conflicts of Interest}

The authors declare that there are no conflicts of interest regarding the publication of this paper.

\section{Acknowledgments}

This work was supported by the Faculty of Science, King Mongkut's Institute of Technology Ladkrabang (KMITL) (grant number 2562-01-05-34). We would also like to acknowledge Associate Prof. Dr. Pattareeya Damrongsak and Mr. Ekkachai Rammarat from the Department of Physics, Faculty of Science, King Mongkut's Institute of Technology Ladkrabang (KMITL), for their excellent assistance in chlorophyll fluorescence emission measurement. We would like to thank Editage (www.editage.com) for English language editing.

\section{References}

[1] J. H. Perry, Chemical Engineers Handbook, McGraw-Hill, New York, NY, USA, 1963.

[2] D. Das and T. N. Veziroǧlu, "Hydrogen production by biological processes: a survey of literature," International Journal of Hydrogen Energy, vol. 26, no. 1, pp. 13-28, 2001.

[3] R. C. Prince and H. S. Kheshgi, "The photobiological production of hydrogen: Potential efficiency and effectiveness as a renewable fuel," Critical Reviews in Microbiology, vol. 31, no. 1, pp. 19-31, 2005.

[4] P. Tamagnini, E. Leitão, P. Oliveira et al., "Cyanobacterial hydrogenases: diversity, regulation and applications," FEMS Microbiology Reviews, vol. 31, no. 6, pp. 692-720, 2007.

[5] T. Takabe, A. Incharoensakdi, K. Arakawa, and S. Yokota, " $\mathrm{CO}_{2}$ fixation rate and RuBisCO content increase in the halotolerant cyanobacterium, Aphanothece halophytica, grown in high salinities," Plant Physiology, vol. 88, no. 4, pp. 1120-1124, 1988.

[6] S. Taikhao, S. Junyapoon, A. Incharoensakdi, and S. Phunpruch, "Factors affecting biohydrogen production by unicellular halotolerant cyanobacterium Aphanothece halophytica," Journal of Applied Phycology, vol. 25, no. 2, pp. 575-585, 2013.

[7] S. Taikhao, A. Incharoensakdi, and S. Phunpruch, "Dark fermentative hydrogen production by the unicellular halotolerant cyanobacterium Aphanothece halophytica grown in seawater," Journal of Applied Phycology, vol. 27, no. 1, pp. 187-196, 2015.

[8] S. Phunpruch, S. Taikhao, and A. Incharoensakdi, "Identification of bidirectional hydrogenase genes and their co-transcription in unicellular halotolerant cyanobacterium Aphanothece halophytica," Journal of Applied Phycology, vol. 28, no. 2, pp. 967-978, 2016.
[9] J. P. Houchins, "The physiology and biochemistry of hydrogen metabolism in cyanobacteria," Biochimica et Biophysica Acta (BBA) - Reviews on Bioenergetics, vol. 768, no. 3-4, pp. 227-255, 1984.

[10] V. D. Samuilov, E. L. Barsky, O. N. Gubanova, V. V. Klimov, and Y. N. Kozlov, "Photoreduction of silicomolybdate in chloroplasts by agents accelerating the deactivation reactions of the water-oxidizing system," FEBS Letters, vol. 357, no. 1, pp. 55-57, 1995.

[11] P. C. Meunier, R. L. Burnap, and L. A. Sherman, "Interaction of the photosynthetic and respiratory electron transport chains producing slow $\mathrm{O}_{2}$ signals under flashing light in Synechocystissp. PCC 6803," Photosynthesis Research, vol. 45, no. 1, pp. 3140, 1995.

[12] M. Torimura, A. Miki, A. Wadano, K. Kano, and T. Ikeda, "Electrochemical investigation of cyanobacteria Synechococcus sp. PCC7942-catalyzed photoreduction of exogenous quinones and photoelectrochemical oxidation of water," Journal of Electroanalytical Chemistry, vol. 496, no. 1-2, pp. 21-28, 2001.

[13] J. M. Pisciotta, Y. Zou, and I. V. Baskakov, "Light-dependent electrogenic activity of cyanobacteria," PLoS ONE, vol. 5, no. 5, Article ID e10821, pp. 1-10, 2010.

[14] Y. Matsuda and B. Colman, "Characterization of sulfate transport in the green alga Chlorella ellipsoidea," Plant \& Cell Physiology (PCP), vol. 36, no. 7, pp. 1291-1296, 1995.

[15] C.-F. Ji, J. Legrand, J. Pruvost, Z.-A. Chen, and W. Zhang, "Characterization of hydrogen production by Platymonas subcordiformis in torus photobioreactor," International Journal of Hydrogen Energy, vol. 35, no. 13, pp. 7200-7205, 2010.

[16] P. G. Heytler, "Uncouplers of oxidative phosphorylation," Methods in Enzymology, vol. 55, pp. 442-462, 1979.

[17] C. Ran, X. Yu, M. Jin, and W. Zhang, "Role of carbonyl cyanide $\mathrm{m}$-chlorophenylhydrazone in enhancing photobiological hydrogen production by marine green alga Platymonas subcordiformis," Biotechnology Progress, vol. 22, no. 2, pp. 438443, 2006.

[18] R. Abdel-Basset and K. P. Bader, "Physiological analyses of the hydrogen gas exchange in cyanobacteria," Journal of Photochemistry and Photobiology B: Biology, vol. 43, no. 2, pp. 146-151, 1998.

[19] D. Yang, Y. Zhang, D. K. Barupal et al., "Metabolomics of photobiological hydrogen production induced by CCCP in Chlamydomonas reinhardtii," International Journal of Hydrogen Energy, vol. 39, no. 1, pp. 150-158, 2014.

[20] Y. Guan, W. Zhang, M. Deng, M. Jin, and X. Yu, "Significant enhancement of photobiological $\mathrm{H}_{2}$ evolution by carbonylcyanide m-chlorophenylhydrazone in the marine green alga Platymonas subcordiformis," Biotechnology Letters, vol. 26, no. 13, pp. 1031-1035, 2004.

[21] Z. Guo, Z. Chen, W. Zhang, X. Yu, and M. Jin, "Improved hydrogen photoproduction regulated by carbonylcyanide $\mathrm{m}$ chlorophenylhrazone from marine green alga Platymonas subcordiformis grown in $\mathrm{CO}_{2}$-supplemented air bubble column bioreactor," Biotechnology Letters, vol. 30, no. 5, pp. 877-883, 2008.

[22] Y. Zhang, X. Fan, Z. Yang, H. Wang, D. Yang, and R. Guo, "Characterization of $\mathrm{H}_{2}$ photoproduction by a new marine green alga, Platymonas helgolandica var. tsingtaoensis," Applied Energy, vol. 92, pp. 38-43, 2012.

[23] H. Imafuku and T. Katoh, "Intracellular ATP level and lightinduced inhibition of respiration in a blue-green alga, anabaena variabilis," Plant \& Cell Physiology (PCP), vol. 17, no. 3, pp. 515524,1976 
[24] R. Shyam, A. S. Raghavendra, and P. V. Sane, "Role of dark respiration in photoinhibition of photosynthesis and its reactivation in the cyanobacterium Anacystis nidulans," Physiologia Plantarum, vol. 88, no. 3, pp. 446-452, 1993.

[25] K. K. Singh, R. Shyam, and P. V. Sane, "Reactivation of photosynthesis in the photoinhibited green alga Chlamydomonas reinhardtii: role of dark respiration and of light," Photosynthesis Research, vol. 49, no. 1, pp. 11-20, 1996.

[26] J. G. Metz, H. B. Pakrasi, M. Seibert, and C. J. Arntzer, "Evidence for a dual function of the herbicide-binding D1 protein in photosystem II," FEBS Letters, vol. 205, no. 2, pp. 269-274, 1986.

[27] M. M. Allen, A. C. Turnburke, E. A. Lagace, and K. E. Steinback, "Effects of photosystem II herbicides on the photosynthetic membranes of the cyanobacterium Aphanocapsa 6308," Plant Physiology, vol. 71, no. 2, pp. 388-392, 1983.

[28] J. Komenda, "Photosystem 2 photoinactivation and repair in the Scenedesmuscells treated with herbicides DCMU and BNT and exposed to high irradiance," Photosynthetica, vol. 35, no. 3, pp. 477-480, 1998.

[29] D. Laval-Martin, G. Dubertret, and R. Calvayrac, "Photosynthetic properties of a DCMU resistant strain of Euglena gracilis Z., Plant Science Letters, vol. 10, no. 2, pp. 185-195, 1977.

[30] Z. Xiankong, K. Haskell, J. B. Tabita, F. R. Tabita, and C. Van Baalen, "Aerobic hydrogen production by the heterocystous cyanobacteria Anabaena spp. strains CA and 1F," Journal of Bacteriology, vol. 156, no. 3, pp. 1118-1122, 1983.

[31] M. Chen, Z. Zhang, C. Wang et al., "Improving conversion efficiency of solar energy to electricity in cyanobacterial PEMFC by high levels of photo- $\mathrm{H}_{2}$ production," International Journal of Hydrogen Energy, vol. 38, no. 31, pp. 13556-13563, 2013.

[32] M. Chen, J. Li, L. Zhang et al., "Auto-flotation of heterocyst enables the efficient production of renewable energy in cyanobacteria," Scientific Reports, vol. 4, Article ID 3998, 2014.

[33] E. Padan, B. Raboy, and M. Shilo, "Endogenous dark respiration of the blue-green alga, Plectonema boryanum," Journal of Bacteriology, vol. 106, no. 1, pp. 45-50, 1971.

[34] M. L. Yallop, "Some effects of light on algal respiration and the validity of the light and dark bottle technique for measuring primary productivity," Freshwater Biology, vol. 12, no. 5, pp. 427433, 1982.

[35] R. Rippka, J. Deruelles, J. B. Waterbury, M. Herdman, and R. Y. Stanier, "Generic assignments, strain histories and properties of pure cultures of cyanobacteria," Journal of General Microbiology, vol. 111, no. 1, pp. 1-61, 1979.

[36] S. Garlick, A. Oren, and E. Padan, "Occurrence of facultative anoxygenic photosynthesis among filamentous and unicellular cyanobacteria," Journal of Bacteriology, vol. 129, no. 2, pp. 623629, 1977.

[37] G. Mackinney, "Absorption of light by chlorophyll solutions," The Journal of Biological Chemistry, vol. 140, no. 2, pp. 315-322, 1941.

[38] S. Joshua, S. Bailey, N. H. Mann, and C. W. Mullineaux, "Involvement of phycobilisome diffusion in energy quenching in cyanobacteria," Plant Physiology, vol. 138, no. 3, pp. 1577-1585, 2005.

[39] T. O. I. V. O. Kallas and R. W. Castenholz, "Rapid transient growth at low $\mathrm{pH}$ in the cyanobacterium Synechococcus sp," Journal of Bacteriology, vol. 149, no. 1, pp. 237-246, 1982.

[40] J. Mottley and D. E. Griffiths, "Minimum inhibitory concentration of a broad range of inhibitors for the unicellular alga Chlamydomonas reinhardi dangeard," Journal of General Microbiology, vol. 102, no. 2, pp. 431-434, 1977.
[41] E. H. Burrows, F. W. R. Chaplen, and R. L. Ely, "Effects of selected electron transport chain inhibitors on 24-h hydrogen production by Synechocystis sp. PCC 6803," Bioresource Technology, vol. 102, no. 3, pp. 3062-3070, 2011.

[42] A. R. Orr, J. E. Kessler, and E. R. TePaske, "DCMU induced inhibition of growth, photosynthesis and motility in eudorina elegans cultures," American Journal of Botany, vol. 63, no. 7, pp. 973-978, 1976.

[43] Y. Gonen-Zurgil, Y. Carmeli-Schwartz, and A. Sukenik, "Selective effect of the herbicide DCMU on unicellular algae - a potential tool to maintain monoalgal mass culture of Nannochloropsis," Journal of Applied Phycology, vol. 8, no. 4-5, pp. 415-419, 1996.

[44] D. Gadkari, "Effect of some photosynthesis-inhibiting herbicides on growth and nitrogenase activity of a new isolate of cyanobacteria, Nostoc G3," Journal of Basic Microbiology, vol. 28, no. 7, pp. 419-426, 1988.

[45] S. Singh, P. Datta, and A. Tirkey, "Response of multiple herbicide resistant strain of diazotrophic cyanobacterium, Anabaena variabilis, exposed to atrazine and DCMU," Indian Journal of Experimental Biology (IJEB), vol. 49, no. 4, pp. 298-303, 2011.

[46] C.-F. Ji, X.-J. Yu, Z.-A. Chen, S. Xue, J. Legrand, and W. Zhang, "Effects of nutrient deprivation on biochemical compositions and photo-hydrogen production of Tetraselmis subcordiformis," International Journal of Hydrogen Energy, vol. 36, no. 10, pp. 5817-5821, 2011.

[47] S. K. Herbert, D. C. Fork, and S. Malkin, "Photoacoustic measurements in Vivo of energy storage by cyclic electron flow in algae and higher plants," Plant Physiology, vol. 94, no. 3, pp. 926-934, 1990.

[48] W. Khetkorn, W. Baebprasert, P. Lindblad, and A. Incharoensakdi, "Redirecting the electron flow towards the nitrogenase and bidirectional Hox-hydrogenase by using specific inhibitors results in enhanced $\mathrm{H}_{2}$ production in the cyanobacterium Anabaena siamensis TISTR 8012," Bioresource Technology, vol. 118, pp. 265-271, 2012.

[49] W. P. Williams and P. J. Dominy, "Control of excitation energy distribution in cyanobacteria: sensitivity to uncouplers and ATP synthase inhibitors," BBA - Bioenergetics, vol. 1015, no. 1, pp. 121130, 1990.

[50] L. Cournac, F. Mus, L. Bernard, G. Guedeney, P. M. Vignais, and G. Peltier, "Limiting steps of hydrogen production in Chlamydomonas reinhardtii, Synechocystis sp. PCC 6803 as analysed by light-induced gas exchange transients," International Journal of Hydrogen Energy, vol. 27, no. 11-12, pp. 1229-1237, 2002.

[51] L. Cournac, G. Guedeney, G. Peltier, and P. M. Vignais, "Sustained photoevolution of molecular hydrogen in a mutant of Synechocystis sp. strain PCC 6803 deficient in the type I NADPH-dehydrogenase complex," Journal of Bacteriology, vol. 186, no. 13, pp. 1737-1746, 2004.

[52] F. Koenig, "A role of the $\mathrm{Q}_{B}$ binding protein in the mechanism of cyanobacterial adaptation to light intensity?" Zeitschrift für Naturforschung C, vol. 42, no. 6, pp. 727-732, 1987.

[53] D. F. Sargent and C. P. S. Taylor, "Light-induced inhibition of respiration in DCMU-poisoned Chlorella caused by photosystem I activity," Canadian Journal of Botany, vol. 50, no. 1, pp. 13-21, 1972. 


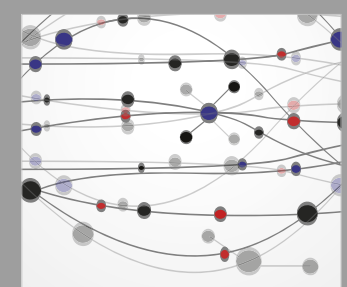

The Scientific World Journal
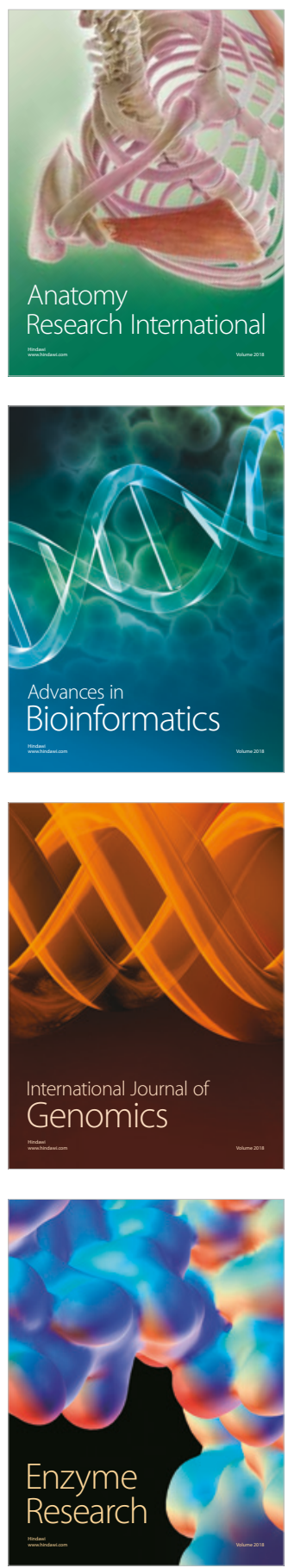
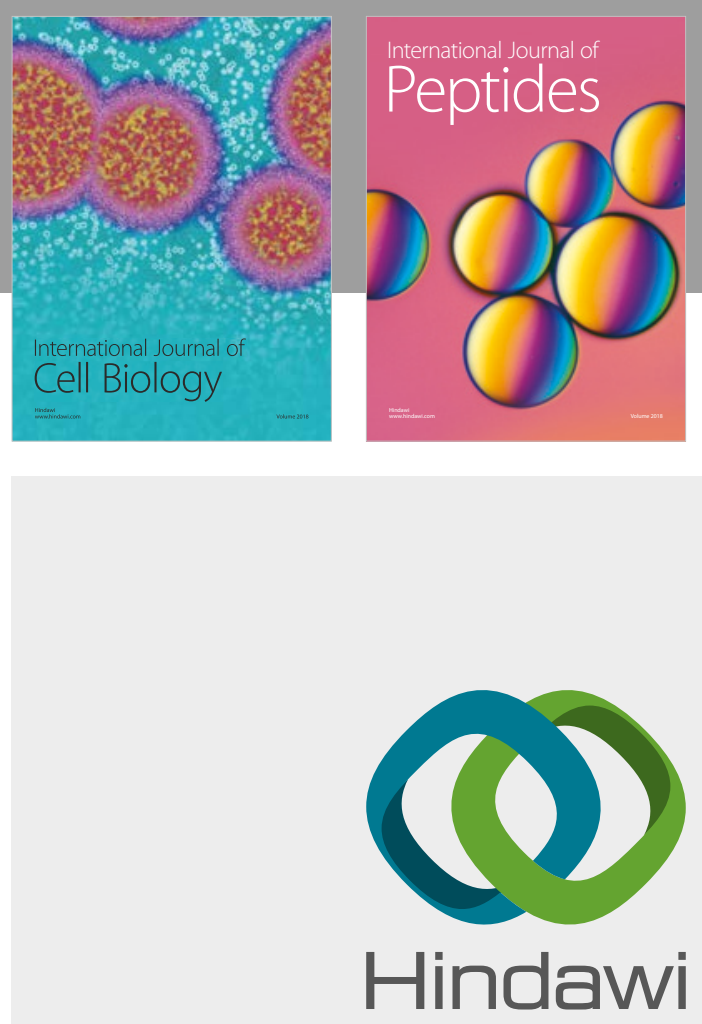

Submit your manuscripts at

www.hindawi.com
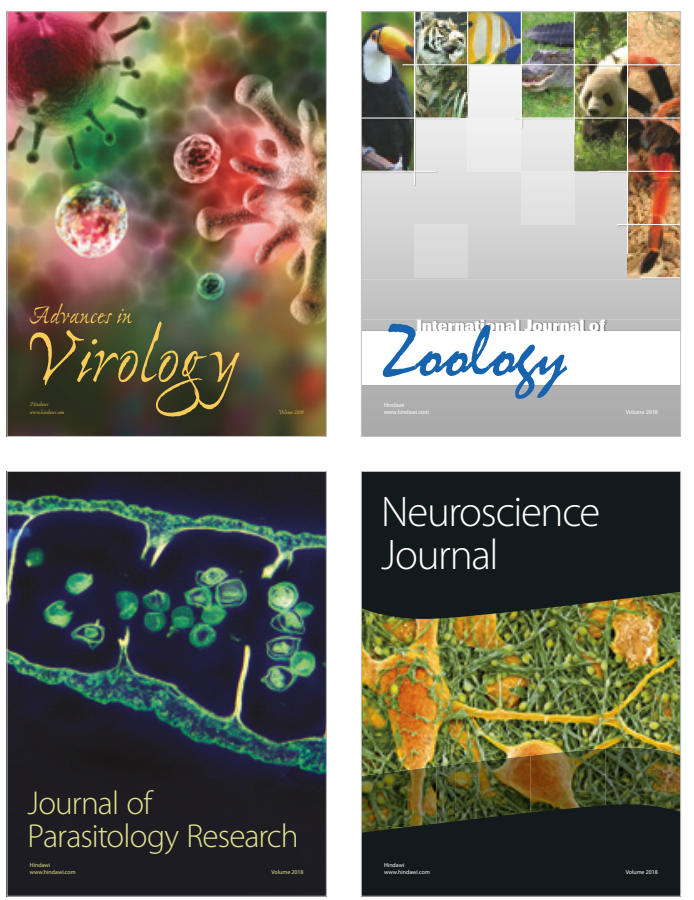
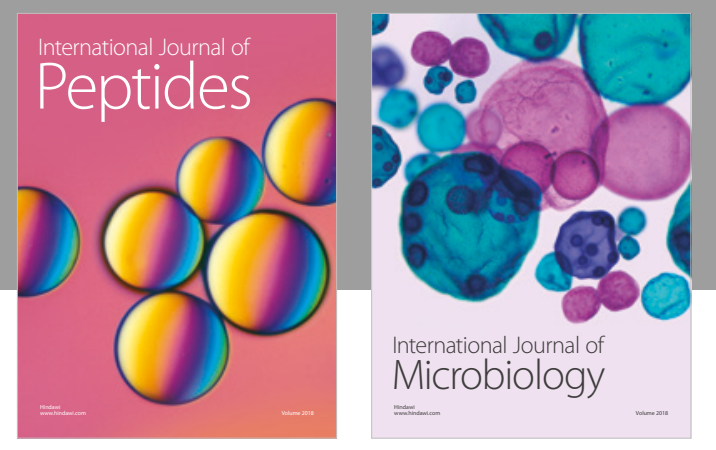

nternational Journal of Microbiology
Journal of
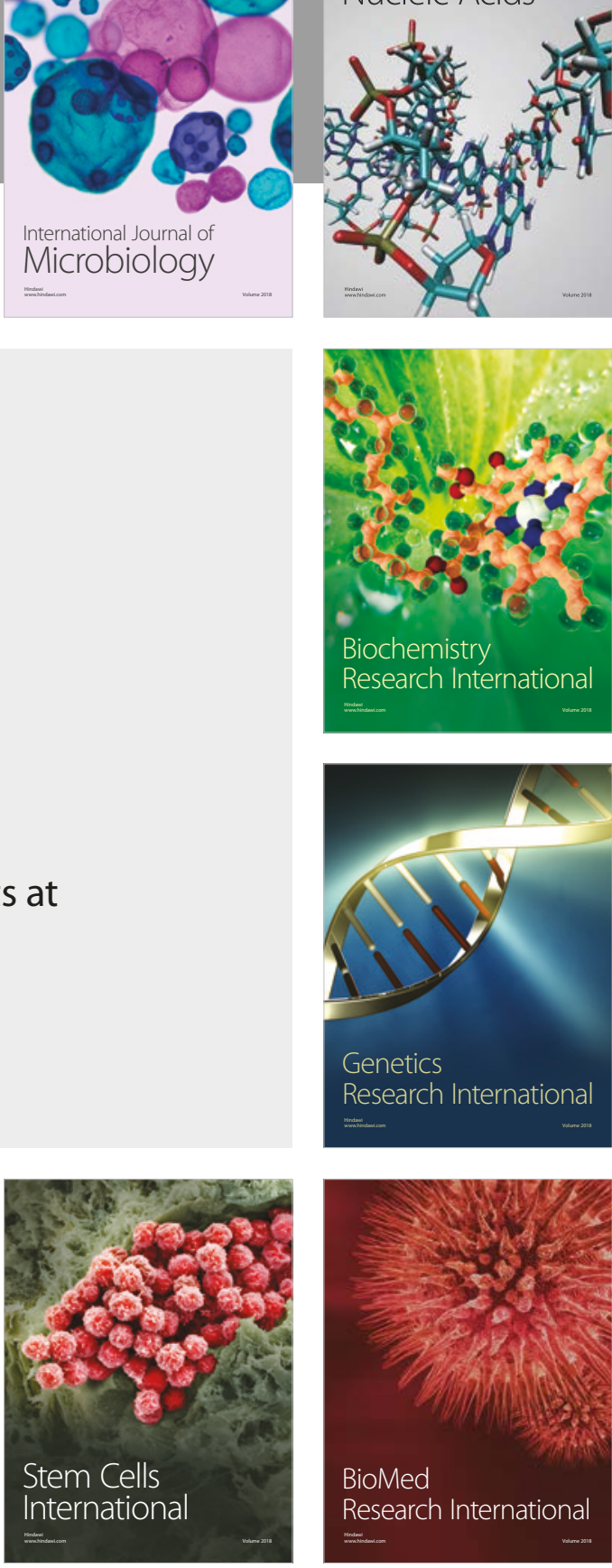
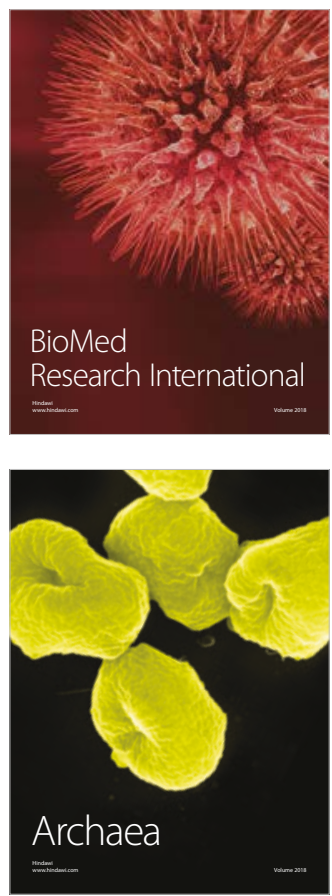